\title{
The Optimization of China's Financial Management Curriculum Design System from the Perspective of Occupational Demand
}

\author{
Fenglin Yuan \\ School of business \\ Yangzhou University \\ Yangzhou, China \\ flyuan@126.com
}

\begin{abstract}
The development of economic globalization, which is deepening, further intensified the competition among the enterprises. Financial management is increasingly becoming the decisive importance of success. Enterprises have become increasingly urgent to need different types of financial management personnel, especially high-level financial management personnel. People in this area are lacking. It manifests that Financial Talent Teaching Program course system in the universities cannot meet the needs of economic development requirements. So to train financial management talents at all levels, who can adapt to the economic development, curriculum design philosophy, curriculum system, the arrangement of semester, study hours and practice system should be optimized.
\end{abstract}

Keywords-occupational demand; financial management professional curriculum system; optimization

\section{INTRODUCTION}

Economic development has attracted worldwide attention on its achievements in the economy since China's reform and opening up have passed for 30 years. National economy annually grew at a speed of around 9\%. China's economic aggregate in 2014 has reached \$10 trillion, and become the world's second largest economy. These achievements cannot be separated from the progress of science and technology, management innovation, and many talents with international viewing and experience. Financial management is the core of management. Financial management talents are the important force for enterprise management in line with the social and economic development. However, financial management major founded in 1998 has not been paid more attention to than accounting major in the aspects of enrollment scale, teachers, discipline construction and curriculum development. In some degree, financial management major seemed to be the vassal of the accounting major. Some schools have taken Financial Management Major subsidiary in the accounting department. Others have similar curriculum design to accounting department. The situation violated original purpose of separation of financial management major from accounting major. Many business missed better opportunities of the M\&A and overseas expansion due to a lack of qualified financial management talent. The paper analyzed the characteristics of the social and economic development and the urgency of demand of financial management talents. The article also disclosed that curriculum system of financial management major will not match with demand for financial talent. Finally some suggestions for optimization of the financial management curriculum system are made.

\section{BACKGROUND OF DEMAND FOR FINANCIAL MANAGEMENT PERSONNEL}

\section{A. The Deepening Trend of Economic Globalization}

The globalization of the economy means that the process of increasing mutual penetration, cross-cutting, mutual interdependence and integration at all levels, during which goods, services, information, technology and a variety of factors of production flow and are allocated in a global context mass and economic activities across national boundaries are on the increase(Jieyao $\mathrm{Bi}, 2006)[1]$. The process of economic globalization means to achieve capital by the process during which capital breaks through barriers of system, mechanisms with the method of market-based resource allocation. In a certain sense, the process of economic globalization from a financial point of view is that capital value-creating process, during which there are financing, investment, finance, mergers, and other financial activities. Therefore there is an urgent demand for financial management personnel in the process of deepening globalization.

\section{B. The Increasing Capital Internationalization}

With the development of modern transportation and communication technologies, favorable conditions have been created for changing the development of the industry with traditional product, regional considered as the link of industry development into the industrial development with capital considered as the link. The rapid development of Transnational Corporations (TNCs) makes capital activities increasingly beyond national borders to search for capital of infinite value. In recent years, multinational corporations have been increasing in China. Statistical data shows that, as of 2011, foreign investors in Shanghai have established 240 investment companies. There are 353 Regional Headquarters of TNCs, and 334 R\&D centers in Shanghai. According to the Ministry of Commerce and National Development and Reform Commission, Chinese absorption of foreign investment in 2014 has reached 119.56 billion dollars [2]. As of 2014, China's nonfinancial foreign investment reached 646.3 billion US dollars. 2. These data indicate that the degree of capital international- 
lization of "going out" and the "IN" of the capital in China is increasingly improved. Capital activities are closely related to the work of financial personnel, and further demonstrate the demand for international finance staff has been growing strong during the process of capital internationalization.

\section{Increasingly Diversified Financial Activities and Complex Financial Relations}

Financial activities mainly include four aspects such as financing, investment, capital use, and distribution in traditional financial management. Under the modern market economic conditions, with the development of the company system and the capital market, the financial activities are in diversity. The ways of financing not only include the traditional indirect financing from banks, but also include direct financing from capital markets, leasing financing, consumer financing, project financing, and other forms of finance. Capital comes not only from the domestic market, but also from foreign market. Investment has its characteristics with cross-border investment, transnational mergers and acquisitions, strategic investments, and other features. The space of financial activities is around the globe. Financial relations related with financial activities have become increasingly complex and diversified. The current financial management career has been put forward higher requirements.

\section{The Entities at All Levels Enhanced the Investment and Wealth Management Awareness}

Along with the growth in our country's economic and social development, people's income level is increasing day by day, and the investment and wealth management awareness of entities at all levels such as state, enterprises, and individuals will become increasingly urgent. At the national level, value preservation and increment for the Social Insurance Fund and the state-owned capital, which is a state-owned infrastructure, is also important manifestation of the superiority of socialism. At the enterprise level, with the ownership of enterprises and the property rights system scientific and clarity, enterprises truly become the 4-self body. The enterprises take up the investment in securities, and financial behavior such as holding shares, M\&A, and reorganization have become increasingly popular. At the social individual level, as property of citizens diversifies, and property income of citizens legalizes, and the financial tools serialize, social individual financing tools becoming richer. The financial risks are also increasing. The financial institutions, private investment advisory bodies, fund management companies, and other financial institutions increasingly need specialized financial management to improve financial management and service capacity.

\section{DEMAND CHARACTERISTICS OF FINANCIAL MANAGEMENT TALENT UndeR THE NEW ENVIRONMENT}

\section{A. Talents with Internationalization Background}

The globalization of the economy and internationalization of capital flow require a lot of talents, including many internationalization financial management personnel. Talents of internationalization financial management should have an international awareness and vision with a first-rate international financial management knowledge structure and internationalization financial management capacity. They can participate in global competition and seize the opportunity and take the initiative. At present, we are lack of these talents.

\section{B. Talents with Multi-faceted Skills}

With the integration of the world economy and the globalization of markets, financial activities are increasingly transcending the boundaries of space and time constraints. Financial transaction types are increasingly diversified. Future financial managers have various skills including communication, PR for financial crisis, due diligence, tax planning, internal control, risk management and control. Lack of these skills will not only affect the company's image, but also lead to passive and loss of production and operations. For example, Sinopec subsidiary in Kazakhstan founded at the inception in 2010 resulted in up-front work flawed and the offthe-books accounts processing lag due to being lack of understanding of the local employment policies, customs clearance requirements, as well as the Government's financial, fiscal and accounting, and other provisions, and lack of multiplayer of finance staff, the language, the project finance and foreign accounting communication is not timely. Finally, the risks and costs of company are very high. There are many such cases.

\section{High-end Talents}

Under conditions of a modern market economy, competition increasingly intensifies. New forms of organization emerged including virtual enterprise, strategic alliances, supply chain alliances and other new forms of organization, as well as transnational corporations, business groups are emerging. The economic business transactions and items have become increasingly complex and diverse. The financial management risks are difficult to deal with, particularly for enterprise group. During the process of the globalization expansion of company group, centralized financial management, total budget management, financial reporting, internal control, financial risk management, financial analysis and decision support, and business performance evaluation need advanced financial management talents with comprehensive skills. In China, chained by traditional system, the current university financial professional personnel training programs and curriculum system urgently need to be improved and optimized. Only in this way can we constantly improve financial management and professional training of personnel quality, enhancing the university graduates of competence and meet the demand for high-end talents.

\section{The Performances Of Insufficiency OF FinANCIAL Management Professional Personnel Training PROGRAM}

\section{A. Uneven Personnel Training Program}

The professional training levels of Financial management personnel are represented by 5 levels. That is vocational school, technical or mechanical degree, undergraduate level, master level and PhD level. According to personnel training programs, different levels should training financial management personnel with different qualities and skills. However, China's master and doctoral programs in most universities are academic tools of instructors. Most graduate students are a little higher in theory but lower in practical ability than undergraduate. They have 
high aims but low abilities and could not be high-level financial management personnel[3]. This kind of curriculum design program not only runs counter to the graduate training goals, but also greatly reduces social adaptive capacity of the graduate. On the one hand, undergraduate students are difficult to be better qualified in modern market economic environment, financial management positions due to the quality of training as well as lack of teaching resources.

\section{B. Lagged Curriculum System Seriously}

Under the conditions of a market economy, the financial management work is increasingly becoming primary important among priorities in business management. Financial personnel not only should know cash management, accounting, financial reporting and financial analysis, but also understand financial planning, financial budget, cost control, capital management, financial allocation, and financial risk management, especially know group finance, as well as transnational corporations finance, foreign currency management, financial PR, internal control, risk management, mergers and acquisitions, reorganization, split, listing, and other financial activities and financial operations[4]. From the capacity perspective, multilanguage ability, expression ability, organization skills, communication skills, decision-making capacity, and public relations skills, information-processing capabilities and information technology capabilities, and more are more important. There is a large gap between the current financial management professional personnel training program and the demand for modern enterprise financial management. Financial management majors most separate in many colleges and universities from accounting majors. Financial management training programs and curriculum system haven't been design in accordance with the nature of financial management and reality career needs. They are got by adjusting accounting talents training program. As a result, many graduates are still taking up accounting positions. It is difficult to adapt to a larger scale of transnational corporations and business group or listed companies, especially for positions in financial department which separate from accounting departments.

\section{Imperfect Practice Teaching System}

Under market economy, the competition among the enterprises is increasingly competitive. Enterprises usually enroll skilled workers with practical experience considering save for costs. It is also the important common characteristics of Human Resources Management. Employing units can hardly provide opportunities for graduates to get to acquire work experience on the basis of commercial secrets, or cost, or difficult to manage, and many other considerations. Many colleges and universities don't have a good practice teaching mode. It is not real-world practice. College graduates who are lack of practical work still face a bleak and lost. Such a practical mode should be perfected.

\section{SUGGESTIONS For OPTIMIZING UNIVERSITY FINANCIAL MANAGEMENT COURSES SYSTEM}

In order to increase the teaching quality and enhance the qualified capacity of financial management university graduates at all levels of work. In my opinion, optimization of course system can be done from four aspects in the following based on the principles of integration between theory and practice, in-school and after-school, hands-on training and practice, a single and comprehensive.

\section{A. To Establish Curriculum Design Concepts Matched with Economic Globalization}

Financial management major is one of majors closely linked to the development of the economy globalization. Financial management training of personnel at all levels whom economy globalization demands for needs the government, the community, schools and employing units to use strategic vision to look at. In particular, the college and university leadership needs to look at financial management training programs and to establish scientific and effective financial management talent cultivation to adapt to the economy globalization of enterprises group, as well as transnational corporations and other types of financial management while rejecting only for small and medium-sized enterprises. In addition, from career development perspective and adapt to the new era innovation of financial activities, financial management courses should be improved and perfected.

\section{B. To Perfect Financial Management Courses System According to Economic Development Requirements}

Financial management courses set up in the different types of schools is different, as well as courses semester and learning timetable. Finally the different colleges train mixed financial management talents [5]. These graduates can not work well to qualify transnational enterprises and business group in its financial management. One reason was because our country's financial management major is young major with the history of more than 10 years. Financial management major is at the exploratory stage. On the other hand, according to the statistics, there are over 200 colleges and universities which have financial management majors. These majors are different. Some are paid more attention, others are paid little attention in fund and teachers and teaching facilities. Totally, financial management training program can not go with the rapid development of market economy in China. Therefore, in order to adapt to future economic development and enhance their professional competitiveness, the financial management department should absorb the free airing of views, in-depth research, and tracking the graduates of the course. In accordance with current transnational corporations and corporate group development, the following courses should be set up and paid more attention, including listing of the company, capital operation, asset reorganization, mergers and acquisitions, financial risk management, internal control, interState Tax differences, financial information, and other financial activities, as well as financing, investment, and distribution in the process of financial innovation activities for transnational corporations financial, internal control, risk management, international tax, capital operation, application of information technology, financial PR, enterprise performance evaluation, and other courses. In addition, a certain amount of bilingual courses should be available to meet financial management positions in theory and internationalization.

\section{To Optimize Courses Semester and Class hours}

The chief of financial management major makes choices of set-up courses, set-up semesters, class hours per week so that including courses and follow-up courses can not be consistent 
and logical in knowledge system. There is no comprehensive feasibility study. Teaching outline can almost be non-existent. For this reason, major leaders of financial management should lead on a regular basis to improve curriculum system to make sure that design of courses system is scientific and logical.

\section{To Establish a Well Practice System}

The Ministry of Education and other six ministries and commissions in China further strengthen practice teaching and learning on January 2012. They made it clear that the humanities and social sciences the undergraduate professional practice teaching weight shall not be less than the total credit (duration) of 15 per cent. Practice teaching and learning should be put in the new talent development programs and become an important part of the system. Class hours and credits should be increased. It can be seen that the education departments pay great attention to practice capacity and job competencebuilding to enrich the hands-on experience of college students. However, as mentioned above, practice teaching is easier said than done. Many colleges and universities consider hands-on training in university as a practice. Performance can not be embodied just as one wish[6]. In my view, the practice teaching system of financial management major can consist of the following seven levels: one is the course hands-on training, such as basic accounting and financial accounting courses hands-on training; second, individual hands-on training, such as case simulations, or sub hands-on training according to the financing, investment; Third, an integrated real-time training, including sub-accounting integrated training and financial management integrated training; Fourth, software training, including accounting software simulation, accounting software interactive hands-on training, the securities investment software applications real-time training, tax simulation, ERP software real-time training, and so on; Fifth ERP sandbox simulation. Sandbox have been important business simulation tools over the past few years that can enhance the real-time training effect; Sixth, the base internship. Under market economy, base construction of colleges and universities ever seems to exist in name only for a long period due to financial management involved business secret. Many enterprises are also not uttering a single word. So the universities should mobilize the enthusiasm of enterprises to strengthen school-enterprise cooperation to provide many opportunities for students' internship; Finally, the final graduation practice. The activities and enthusiasm of parents of students, teachers and the local talent market should be mobilized to create internships conditions for students' employment and career with more experience.

\section{ACKNOWLEDGMENT}

Thanks to the sponsors: Jiangsu Overseas Research \& Training Program for University Prominent Young \& Middleaged Teachers and Presidents (2013); Yangzhou University Humanities and Social Science Project (xjj2013-43)

\section{REFERENCES}

[1] Bi Jiyao, Current Economic Globalization and the New Requirements . China Price,Issue 2,2006
[2] [EB/OL] http://finance.eastday.com/m/20150122/u1a8548354.html

[3] Xiangzhou Chen and Yuzhen Zhao, Study of courses optimization settings undergraduate financial management professional.Theory and Practice of Contemporary Education, Vol.1 No.5 Oct.2009

[4] Quehui Zhen, Respond to innovation and personnel training , improve the university curriculum system. China higher Education,Issue 20,2008

[5] Qibin Liu, Study of Financial Management Course set of Applied Undergraduate University. Commercial Accounting,Issue 1,2012

[6] Eugene F. Brigham \& Lou is C.Gapenski.1997. Financial Management: Theory and Practice, Eighth Edition, the Dryden Press 